\title{
Correlation between hydrolytic enzyme activities measured in bean seedlings after Trichoderma koningii treatment combined with pregermination and the protective effect against Pythium splendens
}

\author{
Alba Marina Cotes, Philippe Lepoivre* and Jean Semal \\ Unité de Phytopathologie, Faculté Universitaire des Sciences Agronomiques, 5030 Gembloux, Belgium (Fax: 32 \\ - 81 610126); * Author for correspondence
}

Accepted 12 February 1996

Key words: damping-off, carboxy methylcellulase, Fpase, endo-1,3- $\beta$-glucanase, endochitinase, biological control

\section{Abstract}

An experimental protocol consisting in the colonisation of pregerminated bean seeds dressed with Trichoderma sp. was used in order to study the mechanisms correlated with the protective effect against Pythium splendens. Seed dressed with TH-11 (T. koningii) for $24 \mathrm{~h}$ presented a higher protective effect and a higher level of seed colonisation as compared to those dressed with TH-13 (T. longibranchiatum). The levels of seed coat colonisation by TH-11 and TH-13 was shown to be correlated with the carboxymethylcellulase activity, as measured in the seed coats retreived from germinating dressed bean seeds. The seed coat colonisation was also associated with an increased activities of endo-1,3- $\beta$-glucanase and endochitinase measured in seed extracts, and an inhibitory effect of seed extracts on Pythium sporangia germination. Pretreatment of TH-13-dressed seeds with a commercial cellulase improved all parameters mentioned above, thus suggesting a role of cellulase activity in the colonisation process and the linked protective effect. The possible role of hydrolytic enzymes in the protective effects is discussed.

\section{Introduction}

Many potential biocontrol agents have already been identified, either as individual microbial strains or as Implex mixtures of microorganisms among which Trichoderma spp. is recognized as promising to control damping-off caused by Pythium spp. in different crops (Adams, 1990; Chet, 1987). Most of these potential biocontrol agents appeared effective under controlled conditions but further improvement of their efficacy is often required to provide economically acceptable and reliable control under field conditions.

The complexity of the interactions between soil microorganisms (antagonists, pathogens, bulk microflora and microfauna), plants and environment, hampered the identification of the causes of the inconsistency in protection activity. The physical, chemical and biotic variables within natural environments not only affect individually each component of the biocontrol system, but also influence their interactions with each other (Hardar et al., 1984; Lewis and Papavizas, 1987).

Seed pregermination combined with Trichoderma spp. treatment is an attractive method for introducing the biocontrol agent onto the infection court of the host (Harman et al., 1989; Mezui M'ella et al., 1994) but also provides a convenient experimental system due to the absence of soil microflora during the occupation phase of the infection court. By combining seed pregermination and Trichoderma spp. treatment, Cotes et al. (1994a) reported that a successful seed coat-coloniser Trichoderma koningii isolate (TH-11) protected bean seeds more efficiently against Pythium splendens and produced more cellulase in a synthetic medium containing seed coats as sole source of carbon than a poor coloniser isolate of Trichoderma longibranchiatum (TH-13). Moreover, once the seed coat colonisation step was carried out, protection could be maintained even after killing Trichoderma sp. with a selective fungicide. 
Different mechanisms, like competition for nutrients in seed exudates, occupation of host infection courts and/or mycoparasitism could be implicated in the protective effect observed. The importance of 1,3$\beta$-glucanase and chitinase as key enzymes responsible for fungal cell and sclerotial wall lysis and degradation has been also reported (Cook and Baker, 1983). In this respect, Elad et al. (1982) found that the ability of 3 isolates of $T$. harzianum to produce hydrolytic enzymes (chitinase, 1,3- $\beta$-glucanase and cellulase) in synthetic liquid medium and in soil, was correlated with their ability to control Pythium sp. and S. rolfsii in vivo.

Based on these observations, the purpose of this study was to analyse the activities of hydrolytic enzymes (cellulase, glucanase and chitinase) in relation with the protection of bean seeds against Pythium in this model system of host-pathogen-protectant.

\section{Materials and methods}

\section{Microorganisms}

T. koningii (strain TH-11) and T. longibranchiatum strain (TH-13) were provided by the Microbiological Research Center, Andes University of Colombia. The isolate of $P$. splendens was isolated in our laboratory from a damped-off bean seedling. The methods for the growth and maintenance of these fungal strains have been previously described (Cotes et al., 1992).

\section{Bean seeds pregermination combined with \\ Trichoderma sp. treatment}

Trichoderma strains were grown on malt extract agar (Difco). Conidia were harvested from 7 day-old colonies by scraping the culture surface with a spatula, and by suspending the propagules in sterile water; the suspension was then filtered through two layers of cheesescloth, and the final spore concentration was adjusted at $10^{7}$ conidia. $\mathrm{ml}^{-1}$.

Bean seeds (Phaseolus vulgaris L. var. Prélude) were surface disinfected for 3 min with successively $3 \%$ sodium hypochlorite and ethanol and washed 3 times for $5 \mathrm{~min}$ with sterile distilled water. Seeds were pregerminated for $24 \mathrm{~h}$ on $0.7 \%$ water agar in Petri dishes kept at $25^{\circ} \mathrm{C}$ with $16 \mathrm{~h} \mathrm{light} \mathrm{photoperiod.} \mathrm{Seeds}$ were then dipped for $30 \mathrm{~min}$ in the spore suspension of TH-11 or TH-13 or in water (control) and pregermination was pursued for $24 \mathrm{~h}$ on $0.7 \%$ water agar in the same conditions of incubation. In order to kill Trichoderma, seeds were then dipped for $30 \mathrm{~min}$ in $4 \mathrm{ppm}$ (a.i.) of the fungicide Sumico ( $25 \%$ diethofencarbe and $25 \%$ carbendazime), or in water (control).

Colonization of bean seed coats by Trichoderma sp. Control or Trichoderma-dressed seeds were retrieved from the water agar every $6 \mathrm{~h}$ for 2 days, and were washed for $3 \mathrm{~min}$ with $0.05 \%$ Tween 20 in sterile distilled water. Seed coats were then collected, ground in a mortar and homogenized with an Ultra-Turrax blender for $1 \mathrm{~min}$ in $10 \mathrm{ml}$ of sterile distilled water. Serial dilutions were prepared immediately and $0.1 \mathrm{ml}$ aliquots were plated on $0.1 \%$ sodium desoxycholate PDA for assay of colony forming units (CFU). The number of Trichoderma colonies were evaluated after 5 days incubation at $25^{\circ} \mathrm{C}$ under $16 \mathrm{~h}$ fluorescent light photoperiod. Trichoderma colonization was express as CFU. $\mathrm{g}^{-1}$ of seed coat.

Inoculation of $\mathrm{P}$. splendens

Inoculation was then carried out by dipping the seeds for $30 \mathrm{~min}$ in water (control) or in suspension of $P$. splendens $\left(10^{3}\right.$ propagules $\left./ \mathrm{ml}\right)$ scraped from 7 dayold cultures grown on corn meal agar (CMA) and suspended in sterile water. Four seeds were placed on $0.7 \%$ water agar in Petri dishes and were incubated for $48 \mathrm{~h}$ at $25^{\circ} \mathrm{C}$ in the growth chamber with $16 \mathrm{~h}$ light photoperiod. Symptom index was then scored according to a visual intensity scale based on the number of necrotic spots in each cotyledon $[1-5$ spots $=$ $20,6-10$ spots $=40,11-15$ spots $=60,16-20=80$ and $>20$ spots (coalescent lesions) $=100$ ]. Protection index was calculated by $(\mathrm{SC}-\mathrm{ST}) / \mathrm{SC} \times 100$ where $\mathrm{SC}=$ symptom index in Trichoderma-untreated control, ST = symptom index after treatment with Trichoderma.

\section{Treatment of bean seeds with cellulase}

Bean seeds pregerminated for $24 \mathrm{~h}$ were pretreated for $3 \mathrm{~h}$ by immersion in a solution $0.5 \% \mathrm{w} / \mathrm{v}$ of cellulase (Onozuka R-10) in $50 \mathrm{mM}$ potassium acetate buffer (pH 5), or in this buffer (control). Seeds were then washed 6 times for 10 min each with sterile distilled water, and dipped for $30 \mathrm{~min}$ in a spore suspension of TH-11 or TH-13. Seeds were then placed for $24 \mathrm{~h}$ in a water agar $(0.7 \%)$ to pursue the pregermination, treated with Sumico, and then inoculated with Pythium as indicated above.

\section{Enzyme extraction}

A weighed portion of seed coats retrieved from Trichoderma sp. -dressed seeds, were harvested and frozen 
at $-20^{\circ} \mathrm{C}$ after Sumico treatment. Homogenates were prepared by grinding in a mortar using dry ice, and diluted in $50 \mathrm{mM}$ potassium acetate buffer ( $\mathrm{pH} \mathrm{5)}$ at a ratio of $1: 2(w / v)$. The extracts were then homogenized with an Ultra-Turrax blender for $2 \mathrm{~min}$. After magnetic stirring ( $1 \mathrm{~min}$ ) and filtration through 2 layers of muslin, the filtrates were centrifuged at 10,000 rpm for $30 \mathrm{~min}$ at $10^{\circ} \mathrm{C}$. The supernatants were dialysed twice for $12 \mathrm{~h}$ against 51 distilled water, and then against $0.01 \mathrm{M}$ potassium acetate ( $\mathrm{pH} 5$ ) overnight. The dialysates were frozen at $-20^{\circ} \mathrm{C}$ and used as seed coat crude extract for enzyme assays.

\section{Enzyme assays}

To determine the 1,3- $\beta$-glucanase (or glucan 1,3- $\beta$-D2. ucosidase) (EC 3.2.1.-) activity, the reaction mixture contained $1 \mathrm{ml}$ seed coat crude extract and $20 \mathrm{mg}$ laminarin (Sigma L 9634) dissolved in $1 \mathrm{ml} 50 \mathrm{mM}$ potassium acetate buffer ( $\mathrm{pH} 5$ ). Reaction mixture with heat-treated seed coat crude extract was included as control. The reaction was incubated at $37^{\circ} \mathrm{C}$ for $1 \mathrm{~h}$ and stopped by boiling for $10 \mathrm{~min}$. A unit of enzymatic activity is the amount of enzyme releasing $1 \mu \mathrm{g}$ glucose equivalents. $g^{-1}$ tissue. $h^{-1}$.

The release of total reducing sugars was measured according to Somogyi (1952) using Nelson's reagents (Nelson, 1944), while free glucose was determined by using glucose oxidase reagent (Sigma) according to manufacturer's instructions. With an exo-1,3- $\beta$ glucanase (EC 3.2.1.58) activity, glucose was the only reaction product, and one unit of activity measured using the Nelson-Somogyi assay equals one unit measured by the glucose oxydase assay. The difference between the results of the two methods represents the

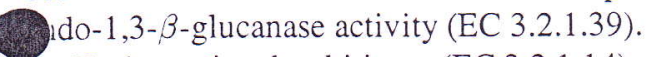

To determine the chitinase (EC 3.2.1.14) activities, the reaction mixture contained $500 \mu 1$ crude enzyme extract, $10 \mathrm{mg}$ chitin (Sigma 3641) in $500 \mu \mathrm{l}$ of $50 \mathrm{mM}$ potassium acetate buffer ( $\mathrm{pH} 5$ ). In the case of endochitinase activity, $500 \mu 1$ of chitobiase (EC 3.2.1.29) $10 \% \mathrm{v} / \mathrm{v}$ (obtained from Canadian lobster lymphatic liquid) was added to the reaction mixture to hydrolyse chitin oligomers, while addition of chitobiase was omitted for determination of exochitinase activity, and substituted by $500 \mu 1$ of potassium acetate buffer. Reaction mixture with heat-treated crude enzyme extract was included as control.

The reaction was incubated at $37{ }^{\circ} \mathrm{C}$ for 10 min and stopped by boiling for $10 \mathrm{~min}$. Enzymatic activity was assayed by measuring the amount of $\mathrm{N}$ - acetylglucosamine (NAGA) according to Reissig et al. (1955). A unit of enzymatic activity is the amount of enzyme releasing $1 \mu \mathrm{g}$ NAGA equivalents. $\mathrm{g}^{-1}$ tissue. $\mathrm{h}^{-1}$.

Two components of the cellulase (EC 3.2.1.4) complex were assayed. Total cellulase complex activity was measured as filter paper activity (Fpase) while carboxymethylcellulase (CMCase) was analysed using carboxymethylcellulose (Hoechst) as substrate. The reaction mixture containing $1 \mathrm{ml}$ crude enzyme, 40 mg Whatman chromatography paper (No. 3001-653) (for Fpase) or $40 \mathrm{mg}$ carboxymethylcellulose (for CMCase), and $1 \mathrm{ml} 50 \mathrm{mM}$ citrate buffer ( $\mathrm{pH} 4.8$ ), was incubated at $48^{\circ} \mathrm{C}$ for $1 \mathrm{~h}$. Reaction mixture with heattreated crude enzyme extract was included as control. Reactions were stopped by boiling for $10 \mathrm{~min}$. Fpase and CMCase activities were evaluated by measuring the release of reducing sugars from the substrates. A unit of enzymatic activity is the amount of enzyme releasing $1 \mu \mathrm{g}$ glucose equivalents. $\mathrm{g}^{-1}$ tissue. $\mathrm{h}^{-1}$

\section{Degradation of mycelium of Pythium by extracts obtained from seed coats}

The hydrolytic activity of seed coat crude extracts from Trichoderma-dressed seeds (TH-11 or TH-13), was tested by using Pythium mycelium as substrate.

Pythium mycelium was obtained by inoculating Erlenmeyer flasks $(500 \mathrm{ml})$ containing $100 \mathrm{ml}$ Difco Potato broth with 4 disks of 7 day-old Pythium culture grown on CMA. Inoculated flasks were incubated for $96 \mathrm{~h}$ at $25^{\circ} \mathrm{C}$ with a $16 \mathrm{~h}$ light photoperiod. Mycelium was then collected by filtering through two layers of cheesecloth, followed by thorough washing with sterile distilled water. Mycelium was mixed with sterile 50 $\mathrm{mM}$ potassium acetate buffer $(\mathrm{pH} 5)$ and was homogenized with a blender for $1 \mathrm{~min}$ at the lowest speed. The suspension was centrifuged at $3000 \mathrm{rpm}$. for 10 min and the precipitate frozen at $-20^{\circ} \mathrm{C}$ was used as substrate in enzyme assays to measure the release of reducing sugars as indicated above.

\section{Sporangia germination assays}

Sporangia of Pythium were prepared by growing the pathogen on CMA at $25^{\circ} \mathrm{C}$ for 4 days in Petri dishes. These plates were then flooded with sterile distilled water for $10 \mathrm{~min}$ (three changes of water), and placed at $10^{\circ} \mathrm{C}$ for 5 days. This procedure resulted in a rapid and synchronous formation of sporangia. Two agar disks $(5 \mathrm{~mm})$ containing sporangia were then placed in one sterile depression well slide $(12 \times 65 \mathrm{~mm})$ and 
mixed with $200 \mu 1$ of either one of the following preparations: seed coats crude extracts, $0.5 \% \mathrm{w} / \mathrm{w}$ cellulase (Onozuka R-10) in $50 \mathrm{mM}$ potassium acetate buffer (pH 5), or $50 \mathrm{mM}$ potassium acetate buffer. These preparations were previously filter-sterilized through a $0.2 \mu \mathrm{m}$ filter (Acrodisk $\mathrm{N}^{\circ} 4192$ ). Heat-inactivated $\left(80^{\circ} \mathrm{C}\right.$ for $20 \mathrm{~min}$ ) or autoclaved $\left(120^{\circ}\right.$ for $20 \mathrm{~min}$ ) seed coat extracts or cellulase preparations were used as controls.

Slides were incubated at $25^{\circ} \mathrm{C}$ into Petri dishes containing a humidified filter paper in order to reach $100 \%$ RH.

Sporangia germination was determined at $6 \mathrm{~h}$ intervals during $24 \mathrm{~h}$, by staining with lactophenol blue. Disks were examined microscopically $(400 \times)$ and the percentage of germinated sporangia recorded. Sporangia were considered germinated if the lenght of the developing tube was twice that of the sporangium. Ten random microscope fields containing 15-30 sporangia per field were counted in each Pythium disk.

\section{Data analysis}

In all inoculation tests or enzymatic assays, three replicates of each treatment were used. All experiments were performed three times independently. Data were subjected to variance analysis $(P=0.05)$, and means were separated with Duncan's multiple range test.

\section{Results}

Comparative study of the protection of bean seed against Pythium with the Trichoderma reference strains (TH11 or TH13)

When bean seed coats were dressed with conidia of TH-11, Trichoderma population increased from an initial level of $8 \times 10^{3} \mathrm{CFU} \cdot \mathrm{g}^{-1}$ to a level of $4 \times$ $10^{5} \mathrm{CFU} . \mathrm{g}^{-1}$ within $48 \mathrm{~h}$ of incubation, whereas with TH-13, population increased from an initial level of $2.5 \times 10^{3} \mathrm{CFU} \cdot \mathrm{g}^{-1}$ to $4 \times 10^{4} \mathrm{CFU} . \mathrm{g}^{-1}$ (Table 1 ).

The ability of TH-11 and TH-13 to protect bean seeds against Pythium sp. was related to the level of seed coat colonisation. After $24 \mathrm{~h}$ incubation of dressed seeds, TH-11 gave a higher protection level (100\%) than $\mathrm{TH}-13(7 \%)$, whereas the protection index provided by $\mathrm{TH}-13$ rose to $76 \%$ if the incubation period was extended up to $48 \mathrm{~h}$.
Effect of seed pregermination, combined with

Trichoderma dressing, on hydrolytic enzyme activity in bean tissue

Preliminary results showed that $1,3-\beta$-glucanase activity appeared to be exclusively an endo-glucanase activity because the release of free glucose from laminarin by extracts from seedcoats previously dressed or not with Trichoderma (TH-11 or TH-13) was null [unpublished data]. Chitinase activity appeared to be also an endochitinase, as no measurable NAGA was detected in the colorimetric exochitinase assay, while NAGA was released if the chitobiase is added to the reaction mixture (endochitinase assay) (but not with heat-treated crude enzyme extract in the control) [unpublished results].

Figure 1 shows that endo-1,3- $\beta$-glucanase, end chitinase and Fpase measured in seed coat extracts obtained from Trichoderma sp.-colonized seeds slowly increased for the whole incubation period and were higher in seed dressed by TH-11 than by TH-13.

On the other hand, the CMCase activities in TH-11 or TH-13 seed coats rapidly increased during the first steps of colonization ( $12 \mathrm{~h}$ incubation) and remained constant after $24 \mathrm{~h}$ incubation, the overall time course of changes being different with the two strains of Trichoderma. Coat extracts from seeds dressed with TH-11 and incubated for $24 \mathrm{~h}$ had CMCase activity around 19-fold higher than undressed control, and 2fold higher than coat extracts prepared from TH-13dressed seeds.

Effect of seed treatment with cellulase Onozuka on the protection effect and on seed coat colonisation by Trichoderma $s p$.

The effect of cellulase pretreatment on the protecti effect of Trichoderma spp. was examined by dipping $24 \mathrm{~h}$-pregerminated seeds for $3 \mathrm{~h}$ in a solution of commercial Onozuka cellulase $(0.5 \% \mathrm{w} / \mathrm{v})$ (containing both Fpase and CMCase activities), or in acetate buffer (control) before treating them with TH-11 and TH-13. After $24 \mathrm{~h}$ incubation, seeds were then treated with Sumico, inoculated with Pythium and incubated for $48 \mathrm{~h}$ before scoring the symptoms (Table 2).

In Trichoderma undressed-control seeds, cellulase pretreatment significantly $(\mathrm{P}=0.05)$ decreased disease severity, compared to control (the protection index reached 3\% in Trichoderma- and cellulase-untreated seeds whereas this index was near $43 \%$ in cellulasetreated seeds). 
Table 1. Effect of seed dressing with Trichoderma spp. (TH11 or TH13) on seed coat colonisation by Trichoderma and seed protection against Pythium

\begin{tabular}{|c|c|c|c|c|c|}
\hline \multirow{2}{*}{$\begin{array}{l}\text { Trichoderma } \\
\text { treatment }\end{array}$} & \multicolumn{3}{|c|}{ Protection index } & \multicolumn{2}{|c|}{$\begin{array}{l}\text { Seed coat colonisation } \\
\left(\log C F U \cdot g^{-1}\right)\end{array}$} \\
\hline & TH-11 & TH-13 & Water & TH-11 & $\mathrm{TH}-13$ \\
\hline \multicolumn{6}{|c|}{ Incubation time (h) } \\
\hline 0 & 0 & 0 & 0 & 3.9 & 3.4 \\
\hline 12 & 0 & 0 & 0 & 4.4 & 3.6 \\
\hline 24 & 100 & 7 & 0 & 4.8 & 3.9 \\
\hline 48 & 100 & 76 & 3.2 & 5.6 & 4.6 \\
\hline
\end{tabular}
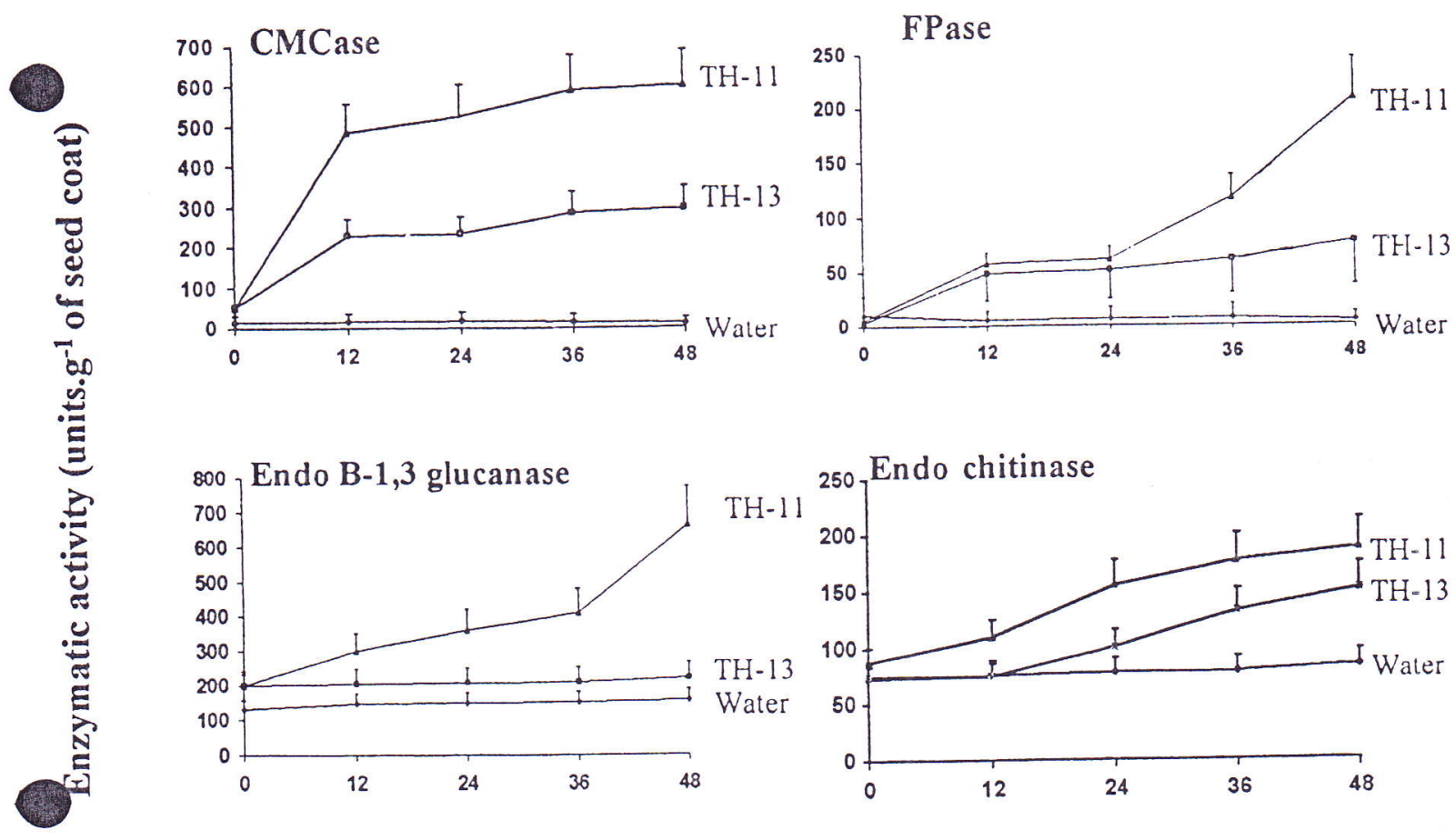

\section{Hours after dressing with Trichoderma}

Figure 1. Time course of enzymatic activities (CMCase, Fpase, endo-1,3- $\beta$ glucanase and endo-chitinase) in crude extracts of coats retrieved from seeds dressed or not with Trichoderma (TH-11 or TH-13). Enzymatic activities were expressed as units. $\mathrm{g}^{-1}$ of seed coats. Vertical bars indicate standard error of the mean of nine data.

Table 2. Effect of cellulase pretreatment on seed coat colonization by Trichoderma sp. and on their protective activities against $P$ ythium

\begin{tabular}{|c|c|c|c|c|c|}
\hline \multirow[t]{3}{*}{ Seed pretreatment } & \multicolumn{2}{|c|}{ Coat colonisation (CFU.g ${ }^{-1}$ ) } & \multicolumn{3}{|c|}{ Protection index (\%) } \\
\hline & \multicolumn{2}{|c|}{ Dressing } & \multicolumn{3}{|c|}{ Dressing } \\
\hline & TH-11 & TH-13 & TH-11 & $\mathrm{TH}-13$ & Control (water) \\
\hline Water & $8.10^{4}$ & $8.10^{3}$ & 100 & 6.8 & 3.2 \\
\hline Cellulase & $1.10^{5}$ & $7.10^{4}$ & 100 & 83.2 & 43.2 \\
\hline
\end{tabular}


TH-11 dressing without cellulase pretreatment significantly $(P=0.05)$ protected bean seeds against Pythium (protection index was 100\%), while TH-13 did not protect them significantly. Seed pretreatment with cellulase, did not modify significantly seed coat colonization, and protection obtained with TH11 dressing, while seed pretreatment with cellulase, followed by TH-13 dressing, increased seed coat colonization from a level of $8 \times 10^{3} \mathrm{CFU} . \mathrm{g}^{-1}$ to $7 \times$ $10^{4} \mathrm{CFU} . \mathrm{g}^{-1}$, and protection increased from $6.8 \%$ to $83.2 \%$ in cellulase and TH-13-treated seeds (Table 2).

Effect of cellulase pretreatment on seed coat enzyme activities after Trichoderma sp. treatment

Very low CMCase and FPase activities (less than 30 units) were found in seed coat extracts obtained from Trichoderma-undressed seeds non pretreated with the cellulase Onuzuka. CMCase and FPase were about 17 and 23 times higher, respectively, in seed coat extracts obtained from Trichoderma-undressed and cellulase pretreated seeds, than in controls (buffer treated seed), whereas no significant differences of endo-1,3- $\beta$-glucanase and endo-chitinase activity were observed in these extracts (Table 3 ).

Seed coat extracts from cellulase-pretreated seeds, colonized for $24 \mathrm{~h}$ with TH-11 or TH-13, contained higher enzymatic activity than extracts obtained from cellulase-untretreated seeds dressed with TH-11 or TH-13 (Table 3). CMCse, Fpase and endo-1,3- $\beta$ glucanase activities were about 4,3 or 2 -fold higher, respectively, in seed coat extracts obtained from cellulase pretreated seeds dressed with TH-13, than in control dressed with TH-13 without cellulase pretreatment whereas endochitinase activities remained unchanged.

\section{Digestion of live Pythium mycelium}

Coat extracts prepared from seeds colonized by these Trichoderma strains were tested for their hydrolytic activity, using mycelium of Pythium as substrate.

Control reaction mixtures containing Pythium mycelium without crude enzymes preparation, or crude enzymes without Pythium, did not release measurable glucose or NAGA during the incubation.

The release of reducing sugars (expressed as glucose equivalents) from Pythium mycelium after treatment with coat extracts of seeds dressed with $\mathrm{TH}$ 11, was more than two fold that of TH-13 (Figure 2) but no NAGA release from live mycelium of Pythium was measured when incubated for $24 \mathrm{~h}, 48 \mathrm{~h}$ or $72 \mathrm{~h}$ with coat extracts of seeds dressed with either one of

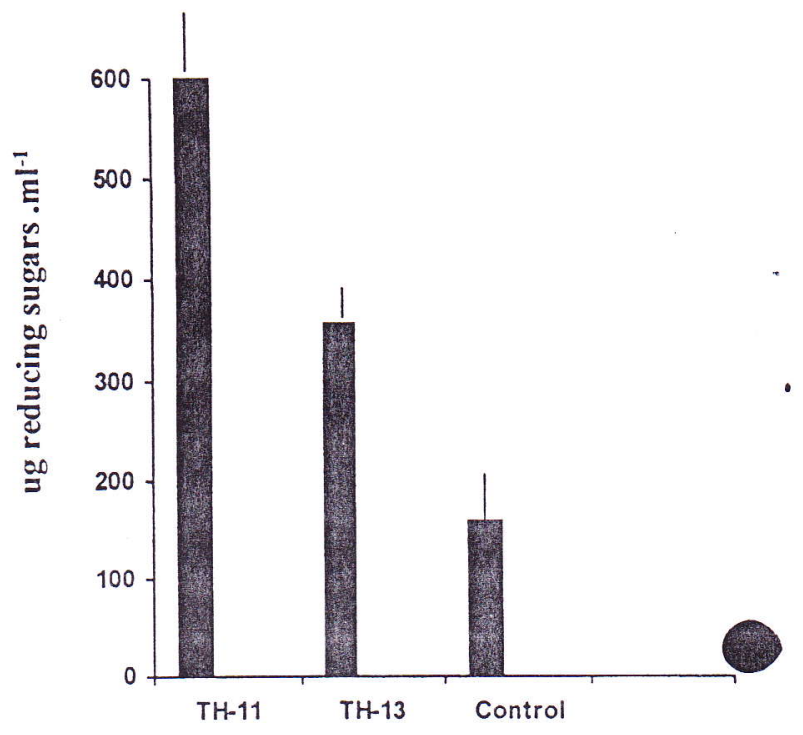

Figure 2. Release of reducing sugars from live mycelium of Pythium by seed coat extracts from undressed seed (control) or from seeds dressed with TH-11 or with TH-13. Vertical bars indicate standard error of the mean for nine data.

the two Trichoderma strains (with or without addition of chitobiase) (unpublished results).

\section{Sporangial inhibition bioassay}

The inhibitory effect of coat extracts on Pythium sporangial germination was examined (Table 4). Application to sporangia of seed coat extracts obtained from $\mathrm{TH}$-11-dressed seeds, reduced germination by about $90 \%$ as compared to sporangia treated with autoclaved extract of undressed seeds.

Seed coat extracts prepared from cellulasepretreated seeds colonized with TH-13, or fro undressed control seeds pretreated with cellulase, also significantly (90\% or $80 \%$, respectively) inhibited germination of sporangia. Inhibition was reduced by diluting the seed coat extracts and abolished after autoclaving seed coat extracts for $30 \mathrm{~min}$.

\section{Discussion}

Our aim has been to contribute to the understanding of a model system of host-pathogen-protectant that might be generalized to other hosts, pathogens or situations. As model, we chose the infection of germinating bean seeds by Pythium sp., which leads to seed rot or damping-off when seeds are planted in a Pythiuminfested substrate under suitable ecological conditions 
Table 3. Enzymatic activities of seed coat extracts obtained from seeds pretreated with cellulase before their dressing and colonisation by Trichoderma sp.

\begin{tabular}{|c|c|c|c|c|c|c|}
\hline \multirow[t]{2}{*}{ Seed pretreatment } & \multirow[t]{2}{*}{ Seed dressing } & \multirow[t]{2}{*}{ Protein $\left(\mu \mathrm{g} \cdot \mathrm{g}^{-1}\right)$} & \multicolumn{4}{|c|}{ Hydrolytic activity (units.g tissue ${ }^{-1}$ ) } \\
\hline & & & CMCse & FPase & $\begin{array}{l}\text { Endo-1,3- } \beta- \\
\text { glucanase }\end{array}$ & $\begin{array}{l}\text { Endo } \\
\text { chitinase }\end{array}$ \\
\hline \multirow[t]{3}{*}{ Buffer } & TH-11 & 42.5 & 546.0 & 739.8 & 377.6 & 154.6 \\
\hline & $\mathrm{TH}-13$ & 27.8 & 240.0 & 578.0 & 233.1 & 101.8 \\
\hline & Water & 11.2 & 28.8 & 25.0 & 166.8 & 84.0 \\
\hline \multirow[t]{3}{*}{ Cellulase } & $\mathrm{TH}-11$ & 96.3 & $1,021.0$ & $2,210.0$ & 500.0 & 172.0 \\
\hline & $\mathrm{TH}-13$ & 60.0 & 954.0 & $1,970.0$ & 521.0 & 152.8 \\
\hline & Water & 48.0 & 482.0 & 568.3 & 166.0 & 74.3 \\
\hline
\end{tabular}

Seed coat extracts were prepared from seeds pretreated for $3 \mathrm{~h}$ with a solution of Onozuka cellulase or acetate buffer (control) and then dressed with TH-11, TH- 13 or sterile water, followed by incubation for $24 \mathrm{~h}$. The levels of standard error of enzyme activities varies from 15 to $20 \%$ between experiments.

Table 4. Sporangia germination of Pythium in the presence of crude seed extracts from seeds pregerminated and dressed with Trichoderma (TH-11 or TH-13)

\begin{tabular}{lrrr}
\hline \multirow{2}{*}{ Seed coat extracts from } & \multicolumn{3}{c}{ Sporangia germination (\%) } \\
\cline { 2 - 4 } & \multicolumn{3}{c}{ Seed coat extract dilution } \\
\cline { 2 - 4 } & $10^{-1}$ & $10^{-2}$ & $10^{-3}$ \\
\hline Seed dressed with: & & & \\
TH-11 & 4.5 & 20.0 & 62.0 \\
TH-11 (autoclaved) & 47.4 & 60.0 & 61.5 \\
TH-13 & 51.0 & 54.0 & 62.2 \\
TH-13 (autoclaved) & 61.6 & 62.2 & 65.3 \\
Water & 56.0 & 58.0 & 60.0 \\
Water (autoclaved) & 70.9 & 67.2 & 69.5 \\
& & & \\
Seeds pretraeted with & & & \\
cellulase followed by & & & \\
dressing with: & & & \\
TH-13 & 7.3 & 28.5 & 51.0 \\
TH-13 (autoclaved) & 68.7 & 72.5 & 71.5 \\
Water & 14.6 & 40.7 & 63.4 \\
Water (autoclaved) & 73.2 & 69.5 & 62.3 \\
50 mM acetate buffer & 61.0 & 60.0 & 62.1 \\
Cellulase & 5.0 & 25.6 & 48.5 \\
Cellulase (autoclaved) & 80.0 & 81.5 & 86.7 \\
\hline
\end{tabular}

Seed coat extracts were prepared from seeds colonised for 24 $\mathrm{h}$ with $\mathrm{TH}-11$ or TH-13. Extracts were autoclaved for $30 \mathrm{~min}$. data are representative of three independantexperiments. The variation coefficient for all treatments were $<12 \%$.

(Mezui M'ella, 1994) or to necrosis of cotyledons in the Petri dish assay used in this study (Cotes et al., 1992).
Possible role of carboxymethycellulase in the protection against Pythium

The level of seed coat colonization by TH-11 or TH-13 after seed dressing was shown to be correlated with the CMCase activity, as measured either in culture filtrates when these strains were grown in synthetic medium containing autoclaved seed coats as sole carbon source (Cotes et al., 1994a,b), or in the seed coats retreived from germinating dressed bean seeds.

Presumably, most of CMCase and FPase activities measured in seed coat extracts from Trichoderma spp.-dressed seeds, were of fungal origin, since only negligible activity was observed in seed coats extracts obtained from water controls (Figure 1). The higher CMCase activity in seed coats, after seeds were dressed with TH-11 (as compared to seeds dressed with TH13), suggests that the ability of TH-11 or TH-13 to hydrolyse the cellulose present in seed coats could be correlated with their colonization capacity. This observation agrees with others (Ahmad and Baker, 1987), where the competitive saprophytic ability of Trichoderma sp., expressed as capacity to colonize the rhizosphere, was directly correlated with the amount of cellulase produced by these strains.

When pregerminated seeds were treated with Onozuka cellulase (obtained from Trichoderma viride cultures and containing both Fpase and CMCase activities), and were then colonized for $24 \mathrm{~h}$ with TH-13 (the inferior colonizer strain), seed coat colonization increased 10-fold in terms of CFU and protection after Sumico treatment increased from $7 \%$ to $83 \%$, as compared to the cellulase-untreated control. We presume that the increased protection index by $\mathrm{TH}-13$ following cellulase pretreatment rests partly on an 
increased seed coat colonization. However cellulase pretreatment of control seeds without Trichoderma dressing also increased protection from $3 \%$ to $43 \%$, thus suggesting that cellulase activity might have a direct inhibition effect toward $P$. splendens. It could also be possible that Trichoderma cellulase acts on the seed tissue by releasing toxic substances that could inhibit Pythium germination or by releasing plant glucans that could act as endogenous elicitors, thus inducing plant responses leading to an increased resistance towards Pythium. The possibility of the presence of other fungitoxic compounds in the commercial preparation of cellulase cannot be ruled out.

Possible role of 1,3- $\beta$-glucanase and chitinase found in bean tissue after dressing with Trichoderma

Combination of the pretreatment with cellulase and $\mathrm{TH}-13$ dressing also increased the endoglucanase and chitinase activities whereas those remained unchanged in Trichoderma undressed control.

A role of such 1,3- $\beta$-glucanase and chitinase activities as defence mechanism was suggested in tomato, where Cladosporium fulvum induced earlier and larger increase of these enzymes in an incompatible hostparasite interaction than in compatible one (Joosten and de Wit, 1988). It has also been shown that both plant 1,3- $\beta$-glucanase and chitinase can release phytoalexin elicitors from fungal cell walls (Cervone et al., 1989; Keen et al., 1983; Kombrink and Hahlbrock, 1986).

It has been shown that plant chitinase and 1,3- $\beta$ glucanase act synergistically in the partial degradation of isolated fungal cell walls (Arlorio et al., 1992; Jones et al., 1974; Young and Pegg, 1982). In this respect, we demonstrated the ability of seed coat glycosidases (cellulase and/or endo-1,3- $\beta$-glucanase) to degrade Pythium cell walls and to liberate reducing sugars. Seed coat extracts from protected bean seeds (dressed with TH-11) induced a larger release of reducing sugars from Pythium cell walls than those from unprotected bean seeds (dressed with TH-13) (Figure 2). This is in accordance with the levels of glycosidase activity in seed coat extracts as measured using laminarin or carboxymethylcellulose as substrates.

Pythium spp. have long been classified among the few fungi whose walls are composed of cellulose and 1,3- $\beta$-glucans (Bartnicki-Garcia, 1968). Chérif et al. (1993) demonstrated the presence of chitin in cell walls of $P$. ultimum, but our study suggests that chitinase (together endo- and exo-chitinases) would not be involved in the degradation of cell walls of our Pythium strain, based on the fact that no $\mathrm{N}$-acetyl glucosamine was released from live mycelium of Pythium submitted to crude coat extracts of Trichoderma-dressed seeds containing chitinase activity.

The interpretation of these results must remain very careful because of the lack of detailed knowledge about the immediate environment of Pythium in a Trichoderma-dressed seed to relate in vitro digestion studies to in situ events. Nevertheless, our demonstration that enzymes contained in seed coat extract are active in vitro towards Pythium mycelium, supports the idea that such enzymes might also degrade the Pythium cell wall during in situ infection.

Our model system of host-pathogen protectant do not provide any experimental evidence about the orig of the chitinase activity extracted from Trichodermadressed seeds. Basically, enzyme extraction combined all possible sources of enzymatic activities: enzymes induced in the plant, and enzymes excreted by Trichoderma. Cotes et al. (1994b) reported that only exo-chitinase activities were released by $\mathrm{TH}-11$ and TH-13 strains of Trichoderma, in culture medium containing autoclaved seed coats as sole carbon source, whereas activities in bean seed coats (both in undressed control seeds or in Trichoderma-dressed seeds), showed only endochitinase activities, suggesting a plant origin in accordance with the characterization of such endoactivity of chitinase (Broglie et al., 1986) in bean leaves. The possibility, however, that Trichoderma sp. releases endochitinase under specific conditions (Lorito et al., 1993), cannot be entirely ruled out. The origin of chitinase activity should be therefore clarified by futher characterization of the enzyme(s) extracted from Trichoderma-dressed seeds.

\section{Antifungal properties of seeds colonized by}

Trichoderma $s p$.

Our results showed that seeds colonized by Trichoderma spp. release a heat sensitive factor(s) in coats, which inhibits sporangia germination of Pythium in vitro. We have shown that enzymes found in seed coat extracts obtained from Trichoderma-dressed seeds could digest mycelium of Pythium and release reducing sugars. Seed coat extracts from bean seeds colonized with TH-11, contained more hydrolytic enzyme activities than those of TH-13 (the less effective biocontrol agent). Upon heat inactivation, such enzyme activities disappeared, together with the inhibition of Pythium sporangia germination. A solution of commercial 
cellulase, exhibiting heat sensitive Fpase and CMCase activities, also inhibited Pythium sporangia germination, strengthening the hypothesis of a contribution of these enzymes in the protective effect observed.

These overall results suggest that the CMCase component of the cellulase complex is involved in the - colonisation process and the linked protective effects measured by symptom index or fungitoxicity of seed extracts.

- On a practical point of view, the application of antagonists by seed dressing is an attractive method for introducing a biocontrol agent onto the infection court of the host. There have been numerous reports of such treatments with Trichoderma for controlling soilborne plant pathogenic fungi (Harman et al., 1980; - ad et al., 1982; Lifshitz et al., 1986). The effects were highly reproducible in terms of emergence percentage, improved vigour of the plantlets and reduced post emergence symptoms, with several crop-pathogen combinations. The results of this study pave the way to a screening protocol for polyvalent microbial strains based on their ability to produce cellulase and to device a schedule of application of biological control agents that would be operational within a wide range of situations and environments.

\section{References}

Adams PB (1990) The potential of mycoparasites for biological control of plant diseases. Ann Rev Phytopatol 28: 59-72

Ahmad JS and Baker R (1987) Rhizosphere competence of Trichoderma harzianum. Phytopathology 77: 182-189

Arlorio M, Ludwig A, Boller T and Bonfante P (1992) Inhibition of fungal growth by plant chitinases and $\beta-1,3$-glucanases. Protoplasma 171: $34-43$

hrtnicki-Garcia S (1968) Cell wall chemistry morphogenesis and taxonomy of fungi. Ann Rev Microbiol 22: 87-108

Broglie KE, Gaynor JJ and Broglie RM (1986) Ethylene-regulated gene expression: molecular cloning of genes encoding an endochitinase from Phaseolus vulgaris. Proc Natl Acad Sci USA. 83: 6820-6824

Cervone F, De Lorenzo G, Salvi G, Bergmann C, Hahn MG, Ito Y, Darvill A and Albersheim P (1989) Release of phytoalexin elicitor-active oligogalacturonides by microbial pectic enzymes. Nato ASI series. Signal Molecules in Plants and Plant-Microbe Interactions 36: 85-89

Chérif M, Benhamou M and Bélanger RR (1993) Occurrence of cellulose and chitin in the hyphal walls of Pythium ultimum: a comparative study with other plant pathogenic fungi. Can J Microbiol 39: 213-222

Chet I (1987) Trichoderma-application, mode of action, and potential as biocontrol agent of soil borme plant pathogenic fungi. In: Innovative Approaches to Plant Disease Control (pp. 137-160) Ed Chet, Wiley \& Sons New York
Cook RJ and Baker KF (1983) The nature and practice of biological control of plant pathogens. St. Paul, Minn: Am. Phytopathol Soc 539 pp

Cotes AM, Lepoivre P and Semal J (1992) Effect of precolonization of bean seeds with Trichoderma, on symptoms induced by Pythium. Med Fac Landbouww Univ Gent 57/2b: 355-363

Cotes AM, Lepoivre P and Semal J (1994a) Correlation between carboxymethycellulase activity, colonization of bean seed coat by Trichoderma, and protection against Pythium In: Diseases and Insects in Forest Nurseries, Dijon (France), October 3-10, 1993 (pp. 179-188) Ed INRA, Paris (Les colloques, $n^{\circ} 68$ )

Cotes AM, Thonart P and Lepoivre P (1994b) Relationship between the protective activities of several strains of Trichoderma against damping-off agents and their ability to produce hydrolytic enzymes activities in soil or in synthetic media. Med Fac Landbouww Univ Gent 59/3a: 931-941

Elad Y, Chet I and Henis Y (1982) Degradation of plant pathogenic fungi by Trichoderma harzianum. Can J Microbiol 28: 719-725

Hadar Y, Harman GE and Taylor AG (1984) Evaluation of Trichoderma koningii and $T$. harzianum from New York soils for biological control of seed rot caused by Pythium spp. Phytopathology 74: 106-110

Harman FE, Taylor AG and Stasz TE (1989) Combining effective strains of Trichoderma harzianum and solid matrix priming to improve biological seed treatments. Plant Disease 73: $631-637$

Harman GE, Chet I and Baker R (1980) Trichoderma hamatum effects on seed and seedling disease induced in radish and pea by Pythium spp. or Rhizoctonia solani. Phytopatology 70: $1167-$ 1172

Jones D, Gordon AH and Bacon SD (1974) Co-operative action by endo and exo- $\beta-(1-3)$-glucanases from parasitic fungi in the degradation of cell-wall glucans of Sclerotinia sclerotiorum (Lib) de Bary. Biochem 140: 47-55

Joosten MH and De wit JGM (1988) Identification of several pathogenesis-related proteins in tomato leaves inoculated with Cladosporium fulvum (syn. Fulvia fulva) as 1,3- $\beta$-glucanases and chitinases. Plant Physiol 89: 945-951

Keen NT, Yoshikawa M and Wang MC (1983) Phytoalexin elicitor activity of carbohydrates from Phytophthora megaspermaf. sp. glycine $a$ and other sources. Plant Physiol 71: 466-471

Kombrink E and Hahlbrock K (1986) Responses of cultured parsley cells to elicitors from phytopathogenic fungi. Plant Physiol 81: 216-221

Lewis JA and Papavizas GC (1987) Application of Trichoderma and Gliocladium in alginate pellets for control of Rhizoctonia damping-off. Plant Pathology 36: 438-446

Lifshitz R, Windham MT and Baker R (1986) Mechanisms of biological control of preemergence damping-off of pea by seed treatment with Trichoderma spp. Phytopathology 76: $720-725$

Lorito M, Harman GE, Hayes CK, Broadway RM, Tronsmo A, Woo SL and Di Pietro A (1993) Chitinolytic enzymes produced by Trichoderma harzianum: Antifungal activity of purified endochitinase and chitobiosidase. Phytopathology 83: 302-307

Mezui M'ella JG, Cotes AM and Lepoivre P (1994) In vitro evaluation of seed priming and Trichoderma treatment for the biological control of damping-off In: Diseases and Insects in Forest Nurseries, Dijon (France), October 3-10, 1993 (pp. 189196) Ed INRA, Paris (Les colloques, $n^{\circ} 68$ )

Nelson N (1944) A photometric adaptation of the Somogyi method for the determination of glucose. J Biol Chem 153: 375-380 
Reissig JL, Srominger JL and Leloir LF (1955) A modified colorimetric method for the estimation of $\mathrm{N}$-acetylamino sugars. J Biol Chem 217: 959-966

Somogyi M (1952) Notes on sugar determination. J. Biol. Chem. 195: 19-23
Young DH and Pegg GF (1982) The action of tomato and Verticillium albo-atrum glycosidases on the hyphal wall of $V$. albo-atrum. Physiological Plant Pathology 21: 411-423 